\title{
PENGARUH PEMASARAN RELASIONAL TERHADAP KEPUASAN NASABAH YANG BERDAMPAK PADA LOYALITAS NASABAH (Studi Pada Nasabah Asuransi Jiwa Bersama (AJB) Bumiputera 1912 Cabang Pematangsiantar)
}

\author{
Klara Delima Agustina \\ Alumni Jurusan Manajemen Fakultas Ekonomi Universitas Negeri Medan \\ T. Teviana \\ Dosen Jurusan Manajemen Fakultas Ekonomi Universitas Negeri Medan
}

\begin{abstract}
Indonesian public awareness the importance insurance Indonesia has been growing rapidly. This condition is seen by the increasing number of insurance companies with a variety of products offered in the community. But even so, awareness of the importance of insurance is not in line with the purchase of an insurance policy. Such conditions make Joint Life Insurance (AJB) Bumiputera 1912 which is a local insurance company to apply the concept of relationship marketing. This study aims to determine the direct and indirect effects of relational marketing consisting of commitment and trust on customer loyalty as well as determine the effect of customer satisfaction on customer loyalty. The population in this study are all policyholders active Joint Life Insurance (AJB) Bumiputera Branch of Pematangsiantar who are customers of at least five years and never filed a claim against the insurance held that as many as 2,750 customers and the sample of 100 people who obtained using the formula slovin with data retrieval random sampling technique. Data was collected by questionnaire at all respondents where the questionnaire was tested beforehand using validity and reliability test on 30 respondents. Technical analysis of the data used is the classical assumption of data normality test, multicollinearity test and linearity test. It is also used path analysis model (path analysis) to examine the direct and indirect influences between variables with hypothesis testing using $t$ test with significance level of 5\% (0.05). The results showed that the partial commitments positive influence directly or indirectly on customer loyalty, trust negative influence directly and positively impact directly on customer loyalty and customer satisfaction directly positive effect on customer loyalty.
\end{abstract}

Keywords: Relational Marketing, Commitment, Trust, Satisfaction, Loyalty

\section{PENDAHULUAN}

\begin{tabular}{rrr}
\multicolumn{2}{c}{ Perkembangan } & zaman yang \\
diikuti dengan & semakin \\
berkembangnya peran & ilmu
\end{tabular} pengetahuan dan teknologi mem-buat kehidupan segelintir masyarakat dari berbagai lapisan mulai mengalami perubahan. Informasi semakin mudah diakses dan hal tersebut disadari atau tidak telah membentuk pola pikir manusia menjadi semakin maju sehingga membuat manusia ingin terus meningkatkan taraf hidup yang lebih tinggi dari sebelumnya. Berdasarkan data Bank Dunia yang dilansir dari situs resmi BPPK Kemenkeu, penduduk kelas menengah di Indonesia tumbuh tujuh juta jiwa setiap tahunnya. Hal tersebut mem-perlihatkan kepada kita bahwa tingkat kesejahteraan masyarakat semakin meningkat sehingga hal tersebut menimbulkan adanya pergeseran ter-hadap kebutuhan yang 
harus dipenuhi termasuk didalamnya kebutuhan untuk hidup aman dan nyaman. Kehadiran industri asuransi pun dinilai telah menjadi jawaban bagi kebutuhan masyarakat terhadap rasa aman dan nyaman dalam jangka panjang. Asuransi jiwa dapat menjadi salah satu alternatif untuk membantu masyarakat memenuhi impian mereka agar memiliki jaminan kehidupan yang terhindar dari risiko tak terduga di masa mendatang seperti penyakit, kecelakaan dan kematian yang tidak pernah diketahui kapan datangnya.

Seiring berjalannya waktu kesadaran masyarakat Indonesia terhadap asuransi dinilai mengalami pertumbuh-an. Namun meskipun demikian kesadaran terhadap pentingnya asuransi tidak sejalan dengan pem-belian polis asuransi. Berdasarkan data yang dilansir dari situs resmi Otoritas Jasa Keuangan (OJK), perkembangan aset asuransi yang lebih rendah jika dibandingkan dengan perkembangan GDP Indonesia me-nyebabkan rendahnya tingkat penetrasi asuransi Indonesia pada tahun 2014 yaitu sebesar $2,14 \%$. (http://www.ojk.go.id).

Asuransi Jiwa Bersama (AJB) Bumiputera merupakan salah satu perusahaan asuransi pribumi yang telah berdiri selama lebih dari seabad. Dengan banyaknya jumlah kantor cabang dan tenaga pemasar, perusahaan ini terus mengembangkan berbagai strategi untuk mencari nasabah baru hingga mempertahankan loyalitas nasabahnya dengan memberikan kepuasan kepada para nasabahnya. Salah satu cara yang dilakukan perusahaan ini adalah dengan menerapkan konsep pemasaran relasional dan terbukti hingga saat ini perusahaan ini merupakan salah satu perusahaan yang masih tetap eksis di bidang perasuransian di Indonesia.

Perusahaan Asuransi Jiwa Bersama (AJB) Bumiputera juga memiliki kantor cabang di Pematangsiantar. Perusahaan yang telah berdiri selama puluhan tahun ini hingga sekarang masih tetap eksis menjadi salah satu perusahaan asuransi yang diminati masyarakat Pematang-siantar. Selama lima tahun terakhir jumlah nasabah asuransi di perusahaan tersebut mengalami fluktuasi. Hal ini dapat dilihat dari tabel 1. berikut.

Tabel 1. Pertumbuhan Jumlah

\begin{tabular}{|c|c|}
\hline \multicolumn{1}{c|}{ Nasabah } \\
\hline 2011 & Jumlah Nasabah \\
\hline 2012 & 4.850 \\
\hline 2013 & 4.910 \\
\hline 2014 & 5100 \\
\hline 2015 & 5070 \\
\hline
\end{tabular}

Sumber: Data Perusahaan AJB Bumiputera Cabang Pematangsiantar

Dari tabel 1. diatas dapat dilihat bahwa selama tiga tahun (2011-2013) perusahaan tersebut masih mampu menambah nasabah baru dan mempertahankan nasabah lama dengan terus membangun hubungan baik dengan para nasabahnya. Namun, pada tahun 2014-2015 terjadi penurunan jumlah nasabah. Hal ini dinilai terjadi akibat semakin beragamnya produk asuransi dan layanan yang diberikan oleh perusahaan pesaing yang sejenis khususnya perusahaan asuransi asing yang mulai menguasai pasar seperti Prudential. Secara nasional PT Prudential Life Insurance mengambil peringkat pertama dalam tiga kategori (berdasarkan aset, premi netto dan 
laba bersih) versi majalah investor sebagai perusahaan asuransi terbaik.

$$
\text { Kondisi yang demikian }
$$

membuat AJB Bumiputera 1912 khususnya cabang Pematangsiantar semakin gencar dalam menerapkan strategi pemasaran relasional untuk mencipta-kan kepuasan nasabah dalam upaya mempertahankan loyalitas nasabahnya. Sebab banyak pakar pemasaran mengemukakan pendapatnya bahwa pemasaran yang berorientasi pada hubungan jangka panjang akan memberikan keuntungan bagi pihak perusahaan maupun nasabahnya.

Hubungan jangka panjang yang disebutkan bermakna penciptaan nasabah yang loyal. Dengan demikian AJB Bumiputera 1912 cabang Pematangsiantar turut membangun komitmen dan kepercayaan nasabahnya dengan meyakinkan pelanggan sekaligus membuktikan bahwa perusahaan ini telah berpengalaman dan diakui sebagai perusahaan asuransi jiwa terbaik di Indonesia. Perusahaan tersebut tetap melayani pemegang polis dan hingga saat ini belum pernah terjadi klaim yang tidak dibayarkan (terkecuali dikarenakan ada agen yang tidak bertanggung jawab membayar-kan premi nasabah kepada pe-rusahaan).

Dengan kondisi yang demikian perusahaan AJB Bumiputera 1912 cabang Pematangsiantar juga menerapkan pembayaran premi melalui bank untuk mencegah ketidak-puasan terhadap nasabahnya, meskipun tetap harus ada kontak dengan agennya. Selain itu untuk memberikan performa terbaiknya, perusahaan secara terus-menerus menyesuaikan diri dengan perusahaan asuransi lainnya dengan menerapkan falsalah baru yaitu semangat (sinergi, empati, moral, aktif, nasionalis, gigih, apresiatif, dan teladan).

\section{KAJIAN PUSTAKA \\ Loyalitas Nasabah}

Loyalitas menjadi bagian penting dalam dunia pemasaran dikarenakan loyalitas merupakan suatu dasar untuk mempertahankan kelangsungan hidup perusahaan. Hasan (2013:125) menyata-kan bahwa Loyalitas nasabah didefenisikan sebagai orang yang membeli secara teratur dan berulang-ulang, mereka secara terus menerus dan berulang kali datang ke suatu tempat yang sama untuk memuaskan keinginannya dengan me-miliki suatu produk atau mendapatkan jasa dan membayar produk tersebut.

Selanjutnya Lovelock dan Wright, 2002 (dalam Jasfar, 2012) menambahkan bahwa loyalitas nasabah berarti nasabah bersedia untuk terus berlangganan pada suatu perusahaan dalam jangka panjang, dengan membeli dan menggunakan barang atau jasanya secara berulangulang, serta dengan sukarela merekomendasikan barang atau jasa perusahaan tersebut kepada teman dan kerabat.

\section{Kepuasan Nasabah}

$\begin{array}{ccc}\text { Secara } & \text { umum, } & \text { Kotler } \\ (2006: 179) & \text { menyatakan } & \text { bahwa }\end{array}$ Kepuasan adalah perasaan senang atau kecewa seseorang yang muncul setelah membandingkan kinerja (hasil) produk yang dipikirkan terhadap kinerja (hasil yang diharapkan). Kepuasan atau rasa senang yang tinggi menciptakan ikatan emosional dengan merek atau perusahaan tersebut, tidak sekadar 
kelebih-sukaan rasional. Selanjutnya bagaimana harapan nasabah dapat terbentuk Kotler (2007:177) juga menyatakan bahwa hal tersebut harus menjadi fokus perusahaan dimana harapan nasabah nyatanya dapat dibentuk dengan memperhatikan pengalaman pembelian mereka sebelumnya, nasihat teman dan kolega, dan janji serta informasi para pemasar dan pesaingnya.

\section{Pemasaran Relasional}

Pemasaran

relasional merupakan salah satu strategi yang diterapkan oleh suatu perusahaan untuk membangun hubungan jangka panjang dengan para nasabahnya. Pemasaran relasional memiliki fokus yang ditekankan pada retensi nasabah ataupun upaya mempertahankan nasabah agar tetap loyal dengan orientasi pada manfaat produk (baik fungsional, emosional maupun eksperiensial) berdimensi jangka panjang (Tjiptono, 2015:184).

Menurut Yau et al.1998 (dalam Yau et.al 1999), pemasaran relasional dapat diukur melalui empat komponen umum yakni ikatan (bonding), empati (empathy), timbal balik (reciprocity) dan kepercayaan (trust). Pemahaman yang lebih mendalam dapat ditemukan dalam penelitian yang dilakukan oleh Morgan dan Hunt (1994) yang mengungkapkan dua aspek kunci sebagai penggerak kerjasama dalam hubungan antara kedua belah pihak, yaitu kepercayaan dan komitmen. Kedua dimensi tersebut yakni komitmen dan kepercayaan akan dijadikan variabel independen dalam penlitian kali ini.

\section{Komitmen}

Menurut Sunarto (2006) dalam tesisnya menyatakan bahwa "komitmen adalah kemauan nasabah untuk tetap memanfaatkan pelayanan yang disediakan oleh bank dimasa datang dan enggan untuk berhenti sebagai nasabah." Hal ini juga berarti bahwa perusahaan harus berupaya keras untuk memberikan pelayanan yang prima sehingga nasabah dapat menerima kepuasan atas pelayanan yang diberikan dan bertahan untuk terus mengkonsumsi produk maupun layanan dari perusahaan industri jasa bukan hanya bank tapi juga industri jasa lain termasuk industri asuransi.

Banyak perusahaan dewasa ini bermaksud mengembangkan komitmen ataupun ikatan yang lebih kuat dengan para nasabah mereka. Ini merupakan proses mengelola informasi rinci tentang masingmasing nasabah dan secara cermat mengelola semua "titik sentuhan" nasabah degan memaksimal-kan kesetiaan nasabah. Informasi memiliki keuntungan karena mudah didiferensiasi, disesuaikan, dipersonalisasi, dan disalurkan lewat network dengan kecepatan luar biasa. (Kotler, 2007:189).

\section{Kepercayaan}

Membangun kepercayaan merupakan kunci dalam membangun hubungan jangka panjang dengan para nasabahnya. Jasfar (2012:16) ber-pendapat bahwa kepercayaan tidak pernah terbentuk dengan sendirinya, sebab kepercayaan nasabah adalah suatu keadaan yang meliputi keyakinan dan harapan nasabah yang positif terhadap janji dari pihak perusahaan yang dapat diandalkan dan dipercaya sehingga 
mengokohkan hubungan kerjasama yang saling menguntungkan.

Soedjas (2006:57) juga menyatakan bahwa "kepercayaan nasabah pada perusahaan serta konsistensi pada pelayanan yang prima selama ini dipercaya dapat menaham beralihnya nasabah ke pesaing". Kepercayaan penting bagi perusahaan karena sebuah perusahaan tidak dapat membangun hubungan yang sebenarnya tanpa adanya kepercayaan.

\section{METODE PENELITIAN \\ Lokasi Penelitian}

Lokasi penelitian ini dilakukan di salah satu kantor cabang Asuransi Jiwa Bersama (AJB) Bumiputera 1912 Cabang Pematangsiantar yang berada di Jl. S. Parman No.3 Siantar Timur, Kota Pematangsiantar, Provinsi Sumatera Utara.

\section{Populasi dan Sampel}

Populasi dalam penelitian ini adalah seluruh pemegang polis aktif Asuransi Jiwa Bersama (AJB) Bumiputera Cabang Pematang-siantar yang telah menjadi nasabah minimal lima tahun serta pernah mengajukan klaim terhadap asuransi yang dimiliki yakni sebanyak 2.750 nasabah. Jadi, jumlah sampel yang digunakan adalah 96,49 responden dan dibulatkan menjadi 100 responden.

\section{Analisis Jalur (Path Analysis)}

Analisis jalur ialah suatu teknik untuk menganalisis hubungan sebab akibat yang tejadi pada regresi berganda jika variabel bebasnya mempengaruhi variabel tergantung tidak hanya secara langsung tetapi juga secara tidak langsung. Analisis jalur digunakan untuk menganalisis pola hubungan antara variabel bebas dengan variabel terikat sekaligus menguji terhadap variabel intervening atau variabel perantara (Ridwan, 2007:2).

HASIL PENELITIAN DAN PEMBAHASAN

\section{Hasil Penelitian}

Analisis Jalur (Path Analysis)

Untuk melihat bagaimana pengaruh secara langsung maupun tidak langsung antar variabel bebas dengan terikat pada analisis jalur maka harus dihitung bedasarkan persamaan struktural yang terdapat pada kerangka berpikir pada bab sebelumnya dimana terdapat dua persamaan struktural sebagai berikut.

Persamaan Struktural I adalah: $\mathrm{Y}_{1}=\mathrm{PY}_{1} \mathrm{X}_{1}+\mathrm{PY}_{1} \mathrm{X}_{2}+\mathrm{e}_{1}$

Persamaan Struktural II adalah: $\mathrm{Y}_{2}=\mathrm{PY}_{2} \mathrm{X}_{1}+\mathrm{PY}_{2} \mathrm{X}_{2}+\mathrm{PY}_{2} \mathrm{Y}_{1}+\mathrm{e}_{2}$

Untuk menguji kebenaran keofesien secara parsial dengan uji t. Dibawah ini terdapat tabel koefisien persamaan struktural I:

Tabel 2. Koefisien Persamaan Struktural I

\begin{tabular}{|c|c|c|c|c|c|c|}
\hline \multicolumn{7}{|c|}{ Coefficients ${ }^{a}$} \\
\hline \multirow{2}{*}{\multicolumn{2}{|c|}{ Model }} & \multicolumn{2}{|c|}{$\begin{array}{l}\text { Unstandardized } \\
\text { Coefficients }\end{array}$} & \multirow{2}{*}{$\begin{array}{c}\text { Standardized } \\
\text { Coefficients } \\
\text { Beta }\end{array}$} & \multirow[t]{2}{*}{$t$} & \multirow[t]{2}{*}{ Sig. } \\
\hline & & $B$ & Std. Error & & & \\
\hline \multirow{3}{*}{1} & (Constant) & 17.052 & 2.646 & & 6.444 & .000 \\
\hline & Komitmen & .162 & .062 & .273 & 2.607 & .011 \\
\hline & Kepercayaan & .384 & .107 & .374 & 3.577 & .001 \\
\hline
\end{tabular}

a. Dependent Variable: Kepuasan

Dari tabel diatas maka dapat diambil persamaan struktural I, yaitu :

$$
\begin{aligned}
\mathrm{PY}_{1} \mathrm{e}_{1} & =\sqrt{1-\mathrm{R}^{2}}=\sqrt{1-0.340}=0.812 \\
\mathrm{Y}_{1} & =\mathrm{PY}_{1} \mathrm{X}_{1}+\mathrm{PY}_{1} \mathrm{X}_{2}+\mathrm{e}_{1} \\
\mathrm{Y}_{1} & =0.273 \mathrm{X}_{1}+0.374 \mathrm{X}_{2}+0.812 \mathrm{e}_{1}
\end{aligned}
$$


Selanjutnya menguji kebenaran keofesien secara parsial dengan uji t. Dibawah ini terdapat tabel koefisien persamaan struktural II:

Tabel 3. Koefisien Persamaan Struktural II

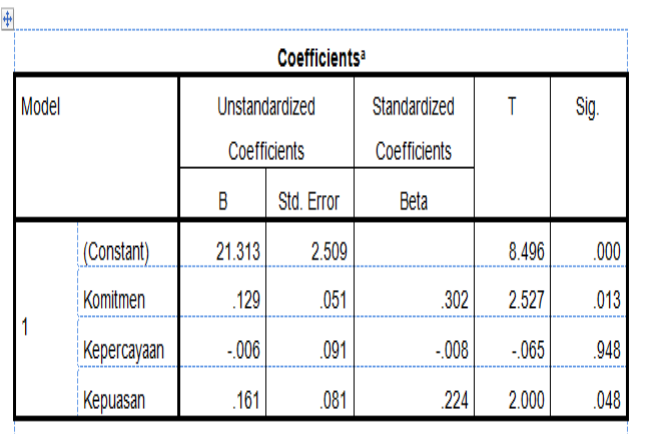

a. Dependent Variable: Loyalitas

Tabel 4. Hasil Koefisien Jalur, Pengaruh Tidak Langsung, Pengaruh Total

\begin{tabular}{|l|r|r|c|c|}
\hline & & \multicolumn{2}{|c|}{ Pengaruh } & \\
\hline Variabel & Koefisien Jalur & Langsung & Tidak Langsung & Total \\
\hline X1 terhadap Y1 & 0.273 & 0.273 & - & 0.273 \\
\hline X2 terhadap Y1 & 0.374 & 0.374 & - & 0.374 \\
\hline X1 terhadap Y2 & 0.302 & 0.302 & $0.273 \times(0.224)=0.061$ & 0.363 \\
\hline X2 terhadap Y2 & -0.008 & -0.008 & $0.374 \times(0.224)=0.083$ & 0.075 \\
\hline Y1 terhadap Y2 & 0.224 & 0.224 & - & 0.224 \\
\hline $\mathrm{e}_{1}$ & 0.812 & 0.812 & - & 0.812 \\
\hline $\mathrm{e}_{2}$ & 0,891 & 0,891 & - & 0.891 \\
\hline
\end{tabular}

Untuk menilai kekuatan pengaruh setiap variabel bebas terhadap variabel terikat digunakan model pada tabel 5 . berikut.

Tabel 5. Kategori Hubungan Pengaruh Variabel yang Diteliti

\begin{tabular}{|c|c|}
\hline Koefisien Path & Daya/Pengaruh \\
\hline $0.05-0.09$ & Lemah \\
\hline $0.10-0.29$ & Sedang \\
\hline$>0.30$ & Kuat \\
\hline
\end{tabular}

Sumber: Sarjono dan Winda (2013)

\section{Pembahasan Penelitian}

Melalui ketentuan diatas maka akan dibahas hasil dari penelitian
Dari tabel diatas maka dapat diambil persamaan struktural II, yaitu: $\mathrm{PY}_{2} \mathrm{e}_{2}=\sqrt{1-\mathrm{R}^{2}}=\sqrt{1-0.205}=0.819$

$$
\begin{aligned}
\mathrm{Y}_{2}= & \mathrm{PY}_{2} \mathrm{X}_{1}+\mathrm{PY}_{2} \mathrm{X}_{2}+\mathrm{PY}_{2} \mathrm{Y}_{1}+\mathrm{e}_{2} \\
\mathrm{Y}_{2}= & 0.302 \mathrm{X}_{1}+-0.008 \mathrm{X}_{2}+ \\
& 0.224 \mathrm{Y}_{1}+0.819 \mathrm{e}_{2}
\end{aligned}
$$

Adapun hasil perhitungan koefisien jalur sub-struktural I dan sub-struktural II dirangkum seluruh hasil koefisien jalur serta pengaruh tidak langsung, dan pengaruh total pada table 4 . berikut. 
hipotesis pertama $\left(\mathrm{H}_{1}\right)$ diterima. Pengaruh variabel komitmen terhadap $\left(\mathrm{X}_{1)}\right.$ terhadap Loyalitas Nasabah $\left(\mathrm{Y}_{2}\right)$ berpengaruh positif secara langsung dalam kategori sangat kuat dikarenakan nilai koefisien jalurnya adalah 0.302 .

\section{Pengaruh Kepercayaan Terhadap Loyalitas Nasabah}

Berdasarkan hasil perhitungan dengan teknik analisis jalur dan uji hipotesis dengan uji t maka dapat disimpulkan bahwa variabel Kepercayaan $\left(\mathrm{X}_{2}\right)$ memiliki pengaruh negatif secara langsung terhadap Loyalitas Nasabah $\left(\mathrm{Y}_{2}\right)$. Artinya hipotesis kedua $\left(\mathrm{H}_{2}\right)$ ditolak dengan nilai koefisien jalur sebesar -0.008 .

\section{Pengaruh Komitmen Terhadap Loyalitas Nasabah Melalui Kepuasan Nasabah}

Berdasarkan hasil perhitungan dengan teknik analisis jalur dan uji hipotesis dengan uji t maka dapat disimpulkan bahwa variabel Komitmen $\left(\mathrm{X}_{1}\right)$ berpengaruh positif secara tidak langsung terhadap Loyalitas Nasabah $\left(\mathrm{Y}_{2}\right)$. Hal ini dikarenakan nilai koefisien jalur secara tidak langsung yang dimediasi oleh variabel kepuasan nasabah sebesar 0.061 . Hal ini berarti hipotesis ketiga $\left(\mathrm{H}_{3}\right)$ diterima dimana komitmen pihak perusahaan menimbul-kan kepuasan nasabah yang pada akhirnya menciptakan loyalitas nasabah terhadap perusahaan untuk tetap meng-gunakan produk yang ditawarkan AJB Bumiputera 1912 Cabang Pematang siantar yang bermanfaat sebagai bentuk perlindungan diri atas risiko yang mungkin terjadi di masa mendatang.

\section{Pengaruh Kepercayaan Terhadap Loyalitas Nasabah Melalui Kepuasan Nasabah}

Berdasarkan hasil perhitungan dengan teknik analisis jalur dan uji hipotesis dengan uji t maka dapat disimpulkan bahwa variabel Kepercayaan $\left(\mathrm{X}_{2}\right)$ berpengaruh positif secara tidak langsung terhadap loyalitas nasabah dengan nilai koefisien jalurnya sebesar 0.083 . Hal ini dikarenakan nilai koefisien jalur secara langsung terhadap variabel kepuasan nasabah benilai 0.083 . Hal ini berarti hipotesis keempat $\left(\mathrm{H}_{4}\right)$ diterima dimana kerpercayaan secara tidak langsung menciptakan loyalitas nasabah melalui kepuasan nasabah atau dengan kata lain terciptanya loyalitas nasabah akibat kepercayaan secara tidak langsung disebabkan karena kepuasan nasabah yang dibangun oleh pihak AJB Bumiputera 1912 Cabang Pematang siantar.

\section{Pengaruh Kepuasan Nasabah Terhadap Loyalitas Nasabah \\ Berdasarkan hasil perhitungan} dengan teknik analisis jalur dan uji hipotesis dengan uji t maka dapat disimpulkan bahwa variabel Kepuasan Nasabah $\left(\mathrm{Y}_{1}\right)$ berpengaruh positif terhadap Loyalitas Nasabah $\left(\mathrm{Y}_{2}\right)$ dimana besarnya koefisien jalur adalah 0.224 . Hal ini berarti hipotesis kelima $\left(\mathrm{H}_{5}\right)$ diterima dimana kepuasan nasabah secara langsung menciptakan loyalitas nasabah. Nasabah yang puas dengan perlakuan yang diberikan oleh pihak perusahaan AJB Bumiputera 1912 Cabang Pematangsiantar pada akhirnya berdampak terhadap terciptanya nasabah yang loyal pada perusahaan. 


\section{PENUTUP}

Berdasarkan hasil analisis dan pembahasan yang telah dilakukan dalam penelitian ini, maka dapat disimpulkan :

1. Komitmen secara parsial berpengaruh positif secara langsung terhadap loyalitas nasabah AJB Bumiputera 1912 Cabang Pematang siantar. Hal ini dapat dilihat dari nilai $\mathrm{t}$ dalam uji hipotesis dan nilai signifikannya dimana nilai $\mathrm{t}_{\text {hitung }}$ untuk variabel komitmen sebesar 2.527, artinya $t_{\text {hitung }}>t_{\text {tabel }}(2.527>1.661)$, dengan taraf signifikan 0,013 yang berarti lebih kecil dari 0,005 $(0,013<0.05)$. Pengaruh variabel komitmen terhadap loyalitas nasabah juga sangat kuat yang dapat dilihat dari nilai koefisien jalur variabel Komitmen $\left(\mathrm{X}_{1}\right)$ sebesar 0.302. Hasil penelitian ini menunjuk-kan bahwa pihak perusahaan AJB Bumiputera 1912 Cabang Pematang siantar telah berkomitmen penuh dalam memberikan pelayanan terbaik bagi nasabahnya sehingga nasabah-nya menjadi loyal.

2. Kepercayaan secara parsial berpengaruh negatif secara langsung terhadap loyalitas nasabah AJB Bumiputera 1912 Cabang Pematang siantar. Hal ini dapat dilihat dari nilai $\mathrm{t}$ dalam uji hipotesis dan nilai signifikannya diman nilai $t_{\text {hitung }}$ untuk variabel kepercayaan sebesar -0.065 artinya $t_{\text {hitung }}<t_{\text {tabel }} \quad(-0.065$ $<1.661)$, dengan taraf signifikan 0.948 yang berarti lebih besar dari $0,05 \quad(0,948 \quad<0.05)$. Hasil penelitian ini menunjukkan bahwa kepercayaan yang dibangun oleh pihak AJB Bumiputera 1912
Cabang Pematang siantar belum mampu menciptakan secara langsung loyalitas nasabah-nya.

3. Komitmen berpengaruh positif secara tidak langsung terhadap Loyalitas Nasabah. Hal ini berarti bahwa kepuasan nasabah memediasi pengaruh komitmen terhadap loyalitas nasabah sehingga dapat juga disimpulkan bahwa komitmen yang dibangun pihak perusahaan terhadap nasabahnya telah mem-berikan kepuasan tersendiri yang pada akhirnya membuat nasabah menjadi loyal terhadap pihak perusahan AJB Bumiputera 1912 Cabang Pematangsiantar. Keadaan ini diperjelas dari hasil perhitungan nilai koefisien jalur sebesar 0.061 dengan pengaruh totalnya sebesar 0.363 .

4. Kepercayaan berpengaruh positif secara tidak langsung terhadap Loyalitas Nasabah. Hal ini berarti bahwa kepuasan nasabah memediasi pengaruh kepercayaan terhadap loyalitas nasabah sehingga dapat juga disimpulkan bahwa nasabah dapat menjadi loyal karena kepercayaan yang diberikan oleh pihak perusahaan namun hal ini terjadi akibar variabel kepuasan nasabah yang memediasi hubungan keduanya. Keadaan ini diperjelas dari hasil perhitungan nilai koefisien jalur sebesar 0.083 dengan pengaruh total sebesar 0.075 .

5. Kepuasan Nasabah berpengaruh positif secara langsung terhadap Loyalitas Nasabah yang berarti bahwa nasabah yang puas telah berkontribusi positif dalam menciptakan nasabah yang loyal pula di AJB Bumiputera 1912 
Cabang Pematangsiantar. Keadaan ini di-perjelas dari hasil perhitungan nilai koefisien jalur sebesar 0.224 .

\section{DAFTAR PUSTAKA}

Anugerahani, Nisa. 2012. Pengaruh

Relationship

Marketing

Terhadap Loyalitas Pelanggan yang Dimediasi Oleh Kepuasan Pelanggan Pada Penumpang Kereta Api Gerbong Khusus Wanita Prambanan Ekspress (Prameks). Fakultas Ekonomi Universitas Sebelas Maret, Surakarta

Griffin, Jill. 2005. Customer Loyalty, Menumbuhkan dan Mempertahankan Kesetiaan Pelanggan. Jakarta: Erlangga

Hasan, Ali. 2013. Marketing dan Kasus-kasus Pilihan. Yogyakarta: CAPS

Jasfar, Farida. 2012. "Teori dan Aplikasi Sembilan Kunci Keberhasilan Bisnis Jasa:Sumber Daya Manusia, Inovasi, dan Kepuasan Pelanggan. Jakarta: Salemba Empat

Kotler, Philip \& Keller L. Kevin. 2006. Marketing Management, Manajemen Pemasaran. Jakarta: Erlangga.

2007. Manajemen Pemasaran, Jilid Kesatu. Jakarta:Erlangga

2012. Manajemen Pemasaran, Jilid 1. Edisi 12. Jakarta: INDEKS

Kuncoro, Mudrajad. 2013. Metode Riset Untuk Bisnis dan
Ekonomi. Edisi 1. Jakarta: Penerbit Erlangga.

Morgan, Robert M. \& Hunt, Shelby D. 1994. The commitment-trust theory of relationship marketing. Journal of Marketing, 58, 20-38

Sanusi, Anwar. 2011. Metodologi Penelitian Bisnis. Jakarta:Salemba Empat

Sarjono, Haryadi dan Winda Julianita.2013.SPSS VS LISREL Sebuah Pengantar Aplikasi untuk Riset. Jakarta:Salemba Empat

Soedjas, Triwibowo dan Bayu Aji Aritejo. 2006. Merebut dan Mempertahankan Pelanggan. Yogyakarta: CV ANDI OFFSET

Syarif, Azmaniar 2008. Pengaruh Pemasaran Relasional Terhadap Kepuasan Pelanggan pada Asuransi Jiwa Bersama (AJB) 1912 Cabang Medan. Tesis Sekolah Pasca Sarjana Universitas Sumatera Utara, Medan

Tjiptono, Fandy dan Anastasia Diana. 2003. Total Quality Management (TQM). Edisi Revisi. Yogyakarta: CV ANDI OFFSET

Tjiptono, Fandy dan Anastasia Diana. 2015. Pelanggan Puas? Tak Cukup!. Yogyakarta: CV Andi Offset

Yau, et al.1999. Is Relationship Marketing for Everyone?. Europan Journal of Marketing, Vol. 34 No. 9/10, 2000, pp. 1111-1127. 